Vol. 17, n 1 | 2013

Varia

\title{
A Case Study of the Impact of Wealth on the Criminal Justice System in Early Nineteenth- Century England
}

Nicola Phillips

\section{(2) OpenEdition \\ Journals}

Electronic version

URL: https://journals.openedition.org/chs/1409

DOI: $10.4000 /$ chs. 1409

ISSN: 1663-4837

Publisher

Librairie Droz

\section{Printed version}

Date of publication: 1 May 2013

Number of pages: 29-52

ISBN: 978-2-600-01718-2

ISSN: 1422-0857

\section{Electronic reference}

Nicola Phillips, "A Case Study of the Impact of Wealth on the Criminal Justice System in Early

Nineteenth-Century England", Crime, Histoire \& Sociétés / Crime, History \& Societies [Online], Vol. 17, $n^{\circ} 1$ । 2013, Online since 01 May 2016, connection on 23 March 2022. URL: http://journals.openedition.org/ chs/1409 ; DOI: https://doi.org/10.4000/chs.1409 


\title{
A Case Study of the Impact of Wealth on the Criminal Justice System in Early Nineteenth-Century England
}

\author{
Nicola Phillips
}

\begin{abstract}
À partir de l'étude du cas des démêlés judiciaires du fils d'un riche et influent marchand de la Compagnie des Indes orientales avec la justice pénale anglaise, de 1812 à 1815, cet article examine les attitudes et les stratégies de sa famille, des avocats et des parties poursuivantes, afin d'évaluer le poids de la fortune et de l'influence aux différents stades du processus pénal. L'article démontre que des questions complexes liées aux allégeances sociales, familiales et politiques déterminaient le moment et les circonstances dans lesquelles les familles fortunées cherchaient ou renonçaient à exercer une influence sur le cours de la justice. Le père comme le fils pouvaient faire jouer un certain nombre de relations familiales et dans les classes supérieures, mais tandis que le fils escomptait leur soutien, le père cherchait au contraire à prévenir celui-ci car il voulait que la justice empêche son fils prodigue de continuer ses escroqueries. Ce faisant, il mêlait bien public et intérêt privé et, tout en insistant sur l'impartialité de la loi, la manière dont il utilisait sa fortune pour s'attacher les services ou renvoyer les avocats, ainsi que sa décision de ne point utiliser ses puissantes relations, eurent un effet considérable à différents moments.
\end{abstract}

Using a case study of the passage of the son of a wealthy, well connected East India Company merchant through the English criminal justice system from 1812 to 1815, this article examines the attitudes and strategies of his family, lawyers and prosecutors in order to assess the impact of wealth and influence at different stages of the judicial process. It demonstrates that complex questions of social, political and family allegiances determined when and how wealthy families chose to apply or abandon attempts to influence the course of justice. Both father and son could call on a number of relatives and elite acquaintances, but while the son expected their support, the father sought to prevent it because he wanted the law to stop his profligate son from defrauding society. In doing so he conflated the public good with private interest and, while he insisted on the impartiality of the law, his use of money to hire or fire legal counsel and his decision not to call on influential connections, was highly instrumental and had a significant impact at different stages.

During the Old Bailey sessions of October 1812 William Collins Burke Jackson, stood in the dock three times on separate charges of forgery, theft

1 Nicola Phillips is Lecturer in History at Kingston University. Her publications include, Women in Business, 1700-1850 (Boydell, Brewer, 2006) and The Profligate Son: A Regency Rake's Progress (OUP, Oxford and Basic Books, New York, 2013). 
and fraud. He was the twenty year old son of a wealthy, highly-respectable East India Company merchant, William Collins Jackson. The Jacksons had an elegant home at 11 Gloucester Place in London's fashionable West End, and Mr Jackson had recently acquired a country estate in Langley, Buckinghamshire - thus adding the trappings of landed gentility to his mercantile wealth. At his father's death William would inherit the estate and a sum in excess of $£ 50,000$, an expectation that shaped his attitude to money throughout his life. Through his mother Jane, he had associations with Anglo-Irish landed elites. Most importantly, her brother, William's maternal uncle, Sir George Shee was an MP and influential Whig, whose career had been greatly helped by the patronage of the esteemed orator and politician Edmund Burke. In the early 1800 s Shee, had, inter alia, strong connections with Lord Castlereagh and Lord Sidmouth, the Home Secretary ${ }^{2}$. William's complete acquittal at the Old Bailey could therefore be ascribed to the advantages conferred on the sons of the wealthy by elite influence and by the discretionary nature of the British criminal justice system. Nevertheless, his conviction for fraud at Gloucester Assizes just five months later would seem to undermine this assertion. It would also conceal the complex internal family politics - the deployment or withholding of wealth and support from elite connections, and negotiations with prosecutors - during William's journey through the criminal justice system.

The debate about the benefits conveyed by the possession of wealth and elite social status on the theory and practice of eighteenth- and early-nineteenth-century justice has been a long running one. Douglas Hay presented the criminal justice system as an ideological force and practical instrument for class control exercised by elite gentlemen to protect their property and position of power. The widely held belief in equality of all before the law was maintained by the judicial exercise of mercy and discretion, bolstered by strict procedural rules and the execution of middle-class forgers and the occasional aristocrat. The influence of powerful gentlemen combined with assurances that the accused came from a good family also "served to save a good number of respectable villains" during the pardoning process $^{3}$. Hay's analysis has been tempered by historians who have painted a picture of English law as "a limited multiple-use right" for all: one designed for the public good, but often directed by private interest and considerably less accessible to the poor $^{4}$. John Langbein contested Hay's thesis on the grounds that the law served to protect the interests of mostly non-elite victims of crime and that discretion was exercised by lower social groups, particularly by prosecutors and jurors, whose decisions were based on ethical grounds rather than class interest. Both Langbein and Peter King have shown that pardoning decisions were made on the basis of a broad range of factors. Indeed King has argued that on the whole "the higher social status of the prisoner or his family was among the least significant factors taken into consideration"5. In his more recent book, King presented a complex picture of the judicial process, in which the varying powers of negotiation and discretion exercised by individuals of different rank at each stage could prove decisive, but

Shee and Castlereagh had both been commended for their roles in suppressing the Irish rebellion of 1798, see Dublin Gazette, 25 October 1798.

Hay (1975, p. 45).

Brewer, Styles (1980, pp. 14-20); Innes, Styles (1986, pp. 402-409).

Langbein (1983, pp. 96-120); King (1984, p. 48). 
that wealth still kept many high status offenders out of the courts ${ }^{6}$. One area in which the wealthy have been shown to be at an advantage was in the use of counsel. Langbein has argued that the adversarial criminal trial produced a 'wealth effect' because the ability to pay for solicitors and skilled lawyers conveyed a significant advantage over those who could not afford their services. Instead of viewing the increasing use of lawyers as a means of protecting the rights of prisoners however, Langbein presented the combative tactics of counsel as a truth defeating mechanism. $\mathrm{He}$ has therefore compared the practices of English criminal trials and the lack of independent magisterial investigative powers at the pre-trial stage unfavourably to European justice systems, which place greater emphasis on ascertaining the truth through interrogating the accused both before and during trial - an argument that has divided historians and modern law practitioners alike ${ }^{7}$. Since the implication is that the greater ability of the rich to pay for skilled barristers meant that they were more likely to avoid conviction, irrespective of guilt, some comparison of early nineteenth-century British and French procedure will also be addressed here.

This article is primarily a case study of the impact of wealth and social status at different stages of the judicial process. It is also an examination of the attitudes and strategies pursued by a wealthy family in their efforts to curb the increasingly illegal activities of their profligate son. Micro-histories, as Gattrell has shown, can be particularly revealing about the (often unconscious) feelings, contemporary attitudes and assumptions concerning the operation of criminal law ${ }^{8}$. Mr Jackson recorded every step of what he saw as his son's descent into depravity: from the age of sixteen when William was absconding from school to consort with prostitutes or buy pornographic literature; through duelling, dismissal from the army and numerous visits to debtors' prisons; to the age of twenty-one when he awaited transportation to Australia. Jackson copied a selection of family letters, which he annotated with his own opinions and narrative sections, into three bound volumes entitled Filial Ingratitude; Or: The Profligate Son. Together with numerous other letters, newspapers and legal records these unpublished volumes form the main sources for this study ${ }^{9}$. Filial Ingratitude provides an insight into Jackson's understanding of William's behaviour, which clearly informed his reaction to his son's arrest and trials. Jackson presented William's story as both a justification of his own parenting and a classic rake's progress. His account therefore followed contemporary understanding of the 'domino theory' of human character, by which all vices were considered as sins of one kind or another that inevitably led on to more serious transgressions that only death or the law could put an end to $^{10}$. Filial Ingratitude was also an attempt to control an aberrant son: William's disappointed

$6 \quad$ King (2000, pp. 360-361).

7 Langbein (2003). For support of the argument that the truth finding capacity of the Anglo-American system is inferior to that of the European see Lord Justice Hooper's review of Origins (2004); for critiques see reviews by Handler (2004); Dwyer (2003). May (2003, pp. 116-117) admits Old Bailey defence counsel tactics could result in acquittal of the guilty, but is more positive about the overall benefits of their activities.

$8 \quad$ Gatrell (1994, pp. 447-496 \& 614).

9 The National Archives (hereafter TNA), C106/65 Filial Ingratitude; Or:The Profligate Son (hereafter $F I$ ) was left unfinished when Jackson died in 1814.

10 Sharpe (1999, pp. 7-10). 
father threatened to publish it if he did not reform his conduct and, while Jackson never executed his threat, this may be because he died before completing the work. Several studies have shown that some plebeian parents chose to make use of courts and prisons to control their delinquent offspring, ${ }^{11}$ but little work has been done on how middle- and upper-class English families dealt with the problem ${ }^{12}$. Moreover, the suggestion that fathers sought their children's conviction either from malicious motives or lack of resources - does not apply in this case ${ }^{13}$. William's father was wealthy but he was also determined to see that the law removed his son from society to protect both his own family and the wider community. I argue that in order to achieve this goal Mr Jackson conflated the public good with private interest; hence although he insisted on the impartiality of the law, he used his money to hire or fire legal counsel and called on influential connections for support, actions which made a significant impact at different stages of the judicial process. It is equally apparent that both father and son, in very different ways, expected or feared that their social status would or ought to make a difference to their experience of, and treatment by, the law.

The extent to which Mr Jackson believed in the ideology of English justice is manifest throughout Filial Ingratitude and at every point of William's career. Indeed it was central to Jackson's identity as an honourable gentleman. He had investigated every instance of William's teenage misbehaviour with forensic thoroughness and conducted 'magisterial' interrogations of all the parties involved. He frequently threatened his son with judicial punishment from the age of sixteen, when he warned William that writing anonymous letters to school bullies would result in "transportation for seven to fourteen years"14. When William's signature began to closely resemble his own, he accused his son of forgery ${ }^{15}$. Not surprisingly, $\mathrm{Mr}$ Jackson later explained to his brother-in-law Sir George Shee, that his "mind [had] been long prepared"16 for William's trial on capital charges. Jackson wholeheartedly embraced the concept of equality before the law and subscribed to the belief that no-one, not even his own son, could be held exempt from it ${ }^{17}$. When William sought sanctuary in his father's house shortly before his arrest, Jackson refused on the grounds that "If you should be demanded of me by those whom you have defrauded I could not in honour and principle secure you for a moment. My house never shall be a sanctuary for the open violation of the Laws of this country"18. Yet, whether consciously or not, such beliefs could also legitimate private motives and in this case it is difficult to separate Jackson's sense of public justice from his personal desire to protect his family's honour, social status and wealth. "For an object so depraved, I

\footnotetext{
11 Emsley (2005, p. 185); King (1998, p. 160); Shore (1999 a, pp. 10-11 \& 31-33).

12 A notable exception is Hunt (1996, pp. 66-67).

13 Shore (1999 b, pp. 108-109).

$14 \quad F I$, Jackson to William, 27 August 1807.

15 FI, Jackson to William, 25 December 1810, p. 118.

16 FI, Jackson to Sir George Shee, 25 September 1812.

17 Hay (1975, pp. 34-35); Brewer, Styles (1980, pp. 14-20).

18 FI, Jackson to William, 26 August, 1812.
} 
will not ruin myself", he told one creditor; but he rationalised this position by arguing that William's debts had been "contracted in defiance of the laws under which I live, and by which I am myself protected"19. Jackson's position was problematic because it was premised on the belief that such laws clearly distinguished between civil offences and criminal actions, when in many cases such distinctions were blurred. It also ignored the fact that "many people took a profoundly instrumental attitude to the law" when deciding whether and how to prosecute ${ }^{20}$.

William's journey to the Old Bailey did not differ greatly from that of many other forgers ${ }^{21}$. His profligate lifestyle created enormous debts that required increasingly desperate means of fending off creditors, in which efforts he was encouraged by his disreputable associates. It was a path that didactic literature and cautionary tales regularly portrayed as a route to the gallows, one for which parents were often blamed. In Sarah More's didactic novel The Cheapside Apprentice (1796), a young man quickly dissipates an inherited fortune and his subsequent execution for forgery is presented as an example of how "a gay life may prove a short one"22. William's position, however, was made more complex by the fact that, despite being liable for prosecution and punishment under criminal law, he was considered a minor under civil law until the age of twenty one. Hence both he and most of his creditors expected his wealthy father to settle his debts ${ }^{23}$. Moreover, when Mr Jackson refused to pay them, many disappointed creditors had to choose between taking civil or criminal action against William - and some tried both. In 1810 William and a friend hired a horse and gig from Joseph Moore, but to fund payment for another debt he left them with another livery stable owner to guarantee a loan of $£ 10$. William was unable to pay back the sum so the stable keeper refused to return the horse and gig to Moore until the debt was paid. Moore tried to persuade Mr Jackson to settle the debt but as he was met with the usual refusal, he announced that he would go to Bow Street police office to press for criminal prosecution. Yet what constituted a criminal act in the case of fraud, particularly when it involved the hiring of horses, was often uncertain and subject to different interpretations according to the context in which the act was committed. Hence Moore and other potential prosecutors weighed up the relative merits of pursuing a civil or criminal action according to which might prove most profitable ${ }^{24}$. Moore eventually sought civil action for debt against both William and his friend, but only William was arrested and such tactics served to convince him that he was the victim of malicious prosecution rather than guilty of a criminal act ${ }^{25}$.

Mr Jackson initially relied on civil law sanctions to restrain his son's profligacy. In continental Europe, elite urban families who worried that the immoral behaviour of their dissolute sons might damage their wealth and reputation could pay public

\footnotetext{
$19 \quad F I$, Jackson to Colley Smith, 8 September 1812.

20 Hay (1989, p. 392).

21 McGowen (1996, pp. 113-129).

22 More (1796), subtitle; for other examples see Gatrell (1994, pp. 156-158).

23 Under criminal law the rule of doli incapax meant that a child was presumed incapable of criminal intent unless proved otherwise until the age of 14. Under civil law William was considered an 'infant' and his father was obliged to pay for all 'necessary' but not 'luxury' purchases according to his rank; however these definitions were frequently disputed in court. See Finn (2003, pp. 14, 239 \& 273-275).

24 King (2000, p. 7).

25 FI, Lt. Greenwell to Jane Jackson, 26 September 1810; William to Jackson, 28 December 1810.
} 
or private prisons to confine them ${ }^{26}$. No such system existed in Britain where the traditional fear of tyranny and secret justice almost certainly prevented its establishment, and the fact that the lettre de cachet was often used by desperate French families to punish profligacy seems not to have been known in England ${ }^{27}$. Nevertheless, Mr Jackson employed very similar tactics. In May 1810 he wrote to the Attorney-general in Guernsey, where William was stationed with his regiment, and requested that he be confined to a debtors' prison. On the continent a profligate son could also be made a ward of a city and held indefinitely under its guardianship. In August 1811 Jackson tried and failed to get the English Lord Chancellor, "as the constitutional guardian of minors" to prevent William defrauding the public any further ${ }^{28}$. Neither method met with success, but three other factors prompted Jackson to consider surrendering his son to the criminal justice system in 1812 . First, he became convinced that William's intentions were criminal and, from a moral perspective, he argued that there was no distinction "between the robber on the Highway and the villain who shall defraud an honest tradesman (...) through false and infamous pretences" ${ }^{29}$. Secondly, this belief was confirmed when William was arrested on charges of theft, fraud and forgery in September 1812. His arrest provoked a local newspaper near their Buckinghamshire estate to brand him a notorious swindler. Soon afterwards, an anonymous letter delivered to Gloucester Place declared that the Jacksons knew that William had deceived "hundreds of credulous tradesmen" but had still failed to stop him ${ }^{30}$. The Jackson family's wealth and status caused the London Morning Post to seize the story and report it in the style of fashionable gossip:

A genteel young man, the son of a gentleman of fortune in Portland Place, the mention of whose name would only tend to distress the feelings of his unfortunate family, was charged, on more than one case, with having offered forged bankers cheques with intention to defraud Prescott \& Co, and others. It appears that the offender has become so incorrigible as to render it next to impossible to receive the countenance of his parents or relatives... ${ }^{31}$.

The publicity surrounding William's arrest further persuaded Jackson that it was his public duty to stop his son's criminal actions by preventing him from escaping the criminal justice system rather than rushing to his defence. In deciding on this course, it could be argued that he followed the jurist William Blackstone's reasoning about the difference between a civil injury to an individual and a criminal action being that "crime and misdemeanours, are a breach and violation of the public rights and duties, due to the whole community" 32 . For these reasons, when Jackson learned

\footnotetext{
26 Spierenburg (2007, pp. 223-250); Lis, Soly (1996, pp. 52-58); Griffiths (2002 pp. 41-58).

27 Emsley $(1999$, p. 319, nt.1).

28 Lis, Soly (1996, p. 52); FI Jackson to Attorney General, Thomas de Saumarez, May 1810; Jackson to Colley Smith, 15 August 1811. Chancery could only appoint a legal guardian for a minor and his living father Jackson was already designated William's guardian.

$29 \quad$ FI, Jackson marginalia to letter from William, 17 June 1813.

30 FI, Jackson to Shee, 25 September, 1812, citing a local paper published in Windsor on 12 September; Anon to Jackson 1812.

31 FI, Charles Day to Jackson enclosing a copy of report in the Morning Post of 4 September 1812.

32 Blackstone (1765-1769) vol. IV, Ch.2.
} 
of William's arrest on criminal charges, he authorised his solicitor, Richard Colley Smith, to help save him from hanging, but not

from any punishment, short of death, for (...) I am morally certain that unless the law can and will restrain him, nothing else will (...) To this point only do my instructions go - for I would not be the means of letting him once more loose on the world for any consideration that the world could offer ${ }^{33}$.

Although Jackson's instructions were clearly meant to limit the extent to which Colley Smith could aid William's case, the ability to hire the services of a solicitor to help prepare a case and employ defence counsel was still one of the advantages from which wealthy defendants could benefit. Colley Smith ran a respectable and prosperous business from Lincoln's Inn in partnership with John Aldridge, Clerk of the Masons Company. The firm had served the Jacksons for many years and dealt primarily with civil law disputes, which is probably why two more attorneys with expertise in criminal cases were hired. Mr Mawley, a Fleet Market attorney, admitted to being in a less "respectable line of the profession" than Colley Smith, but claimed to have thirty years' experience of criminal trials which would prove useful to the solicitor. Given William's associations with London's demi-monde and fraudsters, it is probable that Mawley was either one of the 'Newgate solicitors' who were retained by criminals on a regular basis because of their flexible principles and long experience at the Old Bailey; or, a hedge attorney who scoured the newspapers for information about potentially lucrative arrest cases ${ }^{34}$. Immediately after William's first examination at Marlborough Street police office, Mawley travelled to the Jacksons' estate in Langley. This strongly suggests that he had read the newspaper advertisements announcing the magistrate's decision to hold William for further examination at a later date. Mr Jackson became suspicious when Mawley promised he could save William from an "ignominious death" if only he were "furnished with the proper means" ${ }^{\prime 35}$. Nevertheless Jackson agreed to hire the attorney on Smith's advice. It was not long before both regretted hiring Mawley, whose methods proved that his intentions were to secure William's freedom by any (and often unscrupulous) means.

For Langbein, employing solicitors for the defence or prosecution was not only evidence of the 'wealth effect', it contributed to the suppression of truth through the party-specific collection of evidence and the coaching of witnesses. The discovery of the truth of an accusation was further hampered by an increasingly lawyer-driven pre-trial process at which the defendant did not have to provide any explanation of the charges against him. Langbein contrasts this unfavourably with the independent investigations of French public prosecutors (procureurs) and private interrogations by examining magistrates (juges d'instruction) ${ }^{36}$. At William's second examination at Marlborough Street both Mawley and Colley Smith were present on his behalf

$33 \quad$ FI, Jackson to Colley Smith, 8 September 1812.

34 Langbein (2003, pp. 143-145); King (2000, pp. 94-97); Corfield (1995, pp. 76-77 \& 82), notes a number of 'irregulars', 'hedge attorneys' and 'understrappers' who managed to practice as solicitors without having completed any formal clerkship or enrolment in the profession.

$35 \quad$ FI, p. 71.

36 Langbein (2003, pp. 273-277 \& 332); see Donovan (2010, pp. 42-43), on the role of these positions after Napoleon restored them under his Code of Criminal Procedure in 1808. 
and although they could not prevent his committal for trial, their actions did help to improve his chances of eventual acquittal and stop further charges being brought. Smith had secured the services of an up-and-coming Old Bailey barrister, John Adolphus, to represent William and he also took copious notes throughout the whole proceedings. He sent this information to Jackson, and later to the defence counsel thereby giving them a substantial advantage, since neither defendant nor counsel knew the exact content of an indictment before they stood in court. Only one of the three prosecutors had legal representation: the tailor, Thomas Colville, who had rented a house to William and then discovered that both his tenant and his furniture had vanished ${ }^{37}$. There is no evidence that Richard Robson, an Oxford Street linen draper who accused William of defrauding him of the cost of valuable muslins, had any counsel present, nor Joseph Christian, a linen draper in Wigmore Street who was prosecuting William for paying with a forged note signed in the name of Stephen Harper. The evidence of all three prosecutors was accepted as sufficient to commit William for trial at the Old Bailey, but his situation could have been worse. It was not uncommon for magistrates to place an advertisement of a second hearing if they suspected the accused had committed other crimes, so that other potential prosecutors would have time to press charges. Several more creditors hoping to benefit from William's arrest were present that day, but they delayed taking any action because a rumour that Mr Jackson would pay to protect his son spread through the crowd. This was almost certainly started by Mawley who, against Colley Smith's orders, visited at least three of them to promise they would be reimbursed. Mr Jackson refused to pay, but in the event none of these potential prosecutors were prepared to pursue charges. Colley Smith, who was convinced William would be convicted on the existing charges, believed they would have nothing to gain ${ }^{38}$.

One of the most cited sources for evidence of early nineteenth-century procedural practice is that of visiting French Judge Charles Cottu, who also made frequent comparisons between what he saw in English courts and common practice in French courts. It is less commonly noted that Cottu's work was prompted by a desire to identify ways to improve French criminal procedure and to defend the trial by jury system which was heavily criticised in France. On arrival in England Cottu was strongly guided by the opinions of leading advocate, judge and politician James Scarlett and his former mentor, the criminal law reformer Sir Samuel Romilly ${ }^{39}$. Both men had collaborated on a book of letters that expressed a degree of support for the French Revolution that they later came to regret, when it became clear that the ensuing Terror would convince many to oppose reform of criminal law and policing in England ${ }^{40}$. Cottu's comments therefore, while expressing great 'esteem' for English institutions, were also critical of elements of procedural practice. $\mathrm{He}$ expressed surprise at the lack of questions put to the accused during the public pretrial in England. This contrasted sharply with the private inquisitorial examination

37 The General Evening Post, 8-10 September, p. 2, col.2 names a Mr Barry, probably Robert Barry (d. 1821), see May, (2003, p. 247).

38 FI, Colley Smith to Jackson, 12 September 1812.

39 Cottu (1822, pp. viii, ix \& x-xi).

40 Barker (2004); Melikan (2004); Emsley (1999, pp. 326-328). Romilly had visited Paris in the 1780s, supported radical political reform and written a pamphlet on parliamentary procedure for the Estates General as well as co-authored Letters containing an account of the late revolution in France (1792) with Étienne Dupont to which Scarlett contributed before reconsidering his position. 
conducted by French magistrates that has been proposed as a more efficient method for determining the true facts of a case. Cottu describes the English system as "much inferior to that followed in France" but admits the latter "may be censured for its over-anxiety to produce the culprit's conviction" ${ }^{41}$. The in-depth preliminary investigation, which could include an examination of the suspect's entire life history, resulted in the production of a large and detailed dossier that was sent to court and used by the judge (Président) to question the accused. The judge's often very lengthy interrogation based on this dossier, which could also include the defendant's social life and any previous offences he may have committed, was heavily prejudicial to the prisoner ${ }^{42}$. Given William's long history of debts and the problematic boundaries between criminal and civil offences a pre-trial examination with no lawyer present and the use of the dossier in court could have proved very damaging indeed.

Cottu also commented on the surprising power of the English prosecutor since "the business of prosecution, instead of being performed on the behalf of the public by an officer appointed expressly for the purpose, is committed entirely to the hands of the injured party, who, by this means, becomes the arbiter of the culprit's fate" ${ }^{43}$. In the early stages of the pre-trial process, it has been shown that negotiations between victims of crime and the accused's friends and family played a key role in preventing many cases from ever reaching court. Indeed, King has argued that property offenders from "major landowning families would almost always have been able to buy, bully, or bluster their way out of trouble before matters reached the courts" ${ }^{4}$. Yet Mr Jackson was determined that William should not expect any protection or assistance from his family or relatives because he believed it was "of great necessity that he should learn from experience that if he transgresses the law, there will be no interference to shield him from disgrace and punishment" ${ }^{\prime 4}$. Other members of the family, however, were keen to use their influence to help - probably because the forgery charge was endangering William's life. On hearing of William's arrest for forgery one friend immediately called on Sir George Shee's "humanity (...) to intercede (...) with his family and friends". William's friend feared that he could not himself persuade Joseph Christian, the financially distressed prosecutor, to drop the case because he was not wealthy ${ }^{46}$. Shee arranged a meeting with the draper, but after a lengthy discussion with him, advised Jackson that "without some very prompt and active interference, the result will be most unpleasant. (...) there appears to be but one way in which the calamity can be avoided (...) by buying off the prosecutor" ${ }^{47}$ Shee's advice, carefully erased from Jackson's copy of his letter but still present in the original, was clearly illegal. Had Jackson followed Shee's recommendation he would have been guilty of compounding a felony. The MP seems to have been willing to put family interest ahead of the law, but in refusing Shee's offer of help Jackson justified his decision from a legal standpoint by stipulating that any intervention in the case should be restricted to "aid which the law will

\footnotetext{
Cottu (1822, pp. 36-37).

42 Donovan (2010, pp. 13 \& 42-43).

43 Cottu (1822, p. 38).

44 Beattie (1986, pp. 38-48); King, (2000, pp. 17-35 \& 307).

$45 \quad$ FI, Jackson to Colley Smith, September 1812.

$46 \quad F I$, Fitzgerald to Shee, 22 September 1812.

$47 F I$, and original letter from Shee to Jackson, 23 September 1812.
} 
allow"48. Yet this justification also served his own interests in preventing William from benefiting from his family's position.

In order to emphasize the extent of family condemnation, Mr Jackson did not communicate with or visit his son in Newgate and insisted that any help from himself, should appear to be coming from his solicitor. His one concession to his son's higher social status was to pay for improvement to William's conditions in prison while awaiting trial on the grounds that it might raise his chances of reformation. William's attitude towards his progress through the criminal justice system, however, was re-inforced by his imprisonment in Newgate gaol, where conditions for wealthy, well-connected prisoners could be greatly ameliorated. Appalled at having to mix with the "lowest and vilest miscreants", William wrote to both Colley Smith and his father begging to be moved to the better side of the gaol. The solicitor believed that a sense of guilt and regret for past sins could only be achieved by separating the offender from the evil influences of likeminded associates and forcing him to consider his actions without any diversions ${ }^{49}$. Smith wrote to Jackson asking him to allow William to be moved and explaining that the other "miserable wretches" in the common side would not allow William "to reflect, if so disposed". Nevertheless, he also reassured Jackson that if William was not executed for forgery, he thought it very "probable that the Court will see that he is taken proper care of and has no means of committing other enormities on society for some time to come, during which period it is to be devoutly wished that the Almighty will be graciously pleased to work a reformation in him" ${ }^{50}$. Jackson conceded that William could be moved to The State Side, the very best section of the gaol, reserved for those "whose manners and conduct evince a more liberal style of education." The twelve rooms housed 30-40 men for a charge of two guineas admittance and $10 \mathrm{~s} 6 \mathrm{~d}$ for a single bed or $7 \mathrm{~s}$ to share with another, but here prisoners did not have to pay garnish, and food was plentiful ${ }^{51}$. Such an arrangement usually excluded suspected or convicted felons, so Colley Smith had to pay an extra guinea to get William admitted. This practice was condemned - but not rectified - by politicians, and provoked at least one outraged prisoner to write to a newspaper denouncing such arrangements ${ }^{52}$. William himself was less than grateful for this special treatment and complained to his mother about the "exorbitant rent" he had to pay for his "miserable apartment" 53 . The very existence of this better accommodation separating him from the common criminals, however, served to reinforce his own sense of being, if not entirely above the law, at least worthy of special treatment by it.

Throughout the run up to William's trial at the October Old Bailey sessions, Colley Smith worked hard at gathering evidence, tracking down and interviewing witnesses, hiring the best defence counsel and preparing William's defence. In doing so, as Langbein has argued, his activities were biased towards helping his young client, whom he believed to be guilty. But, they also caused the solicitor many misgivings and he sought to minimise the extent to which the truth was distorted.

\footnotetext{
$48 \quad F I$, Jackson to Shee, 25 September 1812.

49 Ignatieff (1989, pp. 71-73).

$50 \quad$ FI, Colley Smith to Jackson, 12 September 1812.

51 Neild (1812, pp. 415-430); Hansard, vol.27 (1814, pp. 754-755).

52 The Examiner, 6 September 1812; Hansard, vol.18 (1814, p. 74).

$53 \quad$ FI, William to Jane Jackson, 9 October 1812.
} 
He arranged to hire the services of top Old Bailey barristers and two attorneys experienced in criminal law. After Mawley's unscrupulous performance at the pretrial hearing Smith sought to replace him with another attorney, but William was afraid to dispense with his services entirely, despite concerns that Mawley was misappropriating funds for his defence. Smith also visited William in Newgate to help him compose a statement of his version of events. Only wealthy prisoners could afford legal assistance with the preparation of their statements and this practice is seen as another example of how the increasing intervention of counsel silenced the accused, thus limiting the potential for his statements contributing to ascertaining the truth. Even in 1836 the parliamentary Commission on Criminal Law noted the use of such prepared defences was "not at all general, and doubts have been entertained of its propriety" 54 . Smith also personally investigated the claims of prosecutors and spent many hours interviewing and preparing "despicable characters" as witnesses. Most counsel only saw their brief on the day of the trial but, armed with the results of his investigations, Smith ensured that William's barristers were unusually well briefed by arranging a pre-trial strategy meeting four days before the October sessions began ${ }^{55}$ Yet this loyal family friend ${ }^{56}$ was also deeply ambivalent about the morality of a case, whose "real merits are (...) unfortunately too obvious", and could impact badly on his own reputation and his relationship with his other clients. Smith was therefore determined to "pay proper attention to the youth and his defence", but he admitted to Jackson that he would be equally careful not to "disregard what is due to myself, to you, and to my other worthy connexions"57. Perhaps it was this ambivalence or Jackson's instructions to limit William's defence that lay behind the fact that neither Smith nor any defence counsel attended William's first arraignment at the Old Bailey on $17^{\text {th }}$ September. He was forced to put off his trial by affidavit on the grounds that a material defence witness was missing. William, deeply shaken by the experience and afraid of being "sacrificed for want of Counsel", blamed Smith for the omission - if convicted he threatened to publish an open letter condemning the solicitor for "trifling" with both his life and his father's money ${ }^{58}$. It is clear therefore that William believed that only his father's ability to pay for top legal advice could prevent his conviction.

Most historians agree that hiring skilled defence counsel was one of the biggest advantages that wealth could confer ${ }^{59}$. William favoured hiring John Gurney, a successful barrister who had been involved in every previous forgery case involving counsel at the Old Bailey that year. He also wanted Peter Alley and John Adolphus, both of whom were eloquent and very aggressive barristers. Adolphus, who later became a champion of impoverished defendants, was still in the earlier stages of

Cairns (1998, p. 50).

55 FI, Colley Smith to Jackson, 29 and 24 October 1812.

56 FI, William to Colley Smith, 8 October 1812.

$57 \quad$ FI, Colley Smith to Jackson, 23 October 1812.

$58 \quad F I$, William to Jackson, 7 October 1812; William to Colley Smith 9 October 1812.

59 Langbein (2003, p. 2, 314-18); King (2000, pp. 360-361). 
his glittering career, but Alley had great experience and had been involved in most forgery trials held at the Old Bailey that year ${ }^{60}$. From Smith's perspective Alley was a good choice because he had a reputation for being popular with Newgate prisoners, who "knew that, even were the cases against them too clear to leave a doubt, they would have a chance from Mr. Alley's great skill in discovering any defect in the indictment, and the certainty that their prosecutors would be roughly handled" 61 . Smith therefore persuaded William that Alley and Adolphus would be sufficient. Smith's argument was not unreasonable given that only around $28 \%$ of Old Bailey defendants and $21 \%$ of prosecutors had any legal counsel ${ }^{62}$. Yet in all but two of the 12 forgery cases previously tried that year the defendants had employed counsel and half of them had been acquitted ${ }^{63}$. It is likely that these figures reflect both the higher social status of most defendants for forgery and the fact that it was a capital crime. It has been argued that employing several defence counsel was a tactic usually practiced by only the wealthiest clients, often to prevent the opposition from acquiring their services ${ }^{64}$, but most forgery defendants employed two defence counsel at the Old Bailey that year. The costs to Jackson were substantial but relatively modest compared to the size of William's debts (c. $£ 800$ in one year) or the size of Jackson's fortune. Jackson paid Smith and Fletcher £156, but it is not clear if this also covered the barristers' fees, which were usually much lower than solicitors'. John Gurney charged 10 guineas for an embezzlement case in $1812^{65} . \mathrm{Mr}$ Jackson, however, considered this a major sum and it was still considerably more than William's prosecutors were willing or able to pay. Colley Smith confirmed that the prosecutor for forgery "relied on the strength and plainness of his case and had no professional assistance" 6 . There is no evidence to show that either of the other two employed counsel, even though one of them had done so at the committal hearing. By contrast Adolphus had appeared for William at that hearing and therefore had prior knowledge of the case before he entered the Old Bailey courtroom, and both he and Alley had been thoroughly briefed by Smith.

The reports of William's first two trials in the Old Bailey proceedings are brief and the third is not recorded at all, but Colley Smith's account of what happened fills in many gaps. His report to Jackson shows that a combination of skilled counsel and the court's insistence on procedural technicalities ensured William's acquittal on six counts of forgery, despite overwhelming evidence to the contrary and $\mathrm{Mr}$ Jackson's belief that only a merciful jury could save his son's life. Since the jury consisted entirely of the kind of craftsmen and traders William had often deceived

${ }_{60}$ The Proceedings of the Old Bailey, search for forgery cases in 1812 (accessed 9 July, 2008) [http :// www.oldbaileyonline.org/search.jsp ?foo=bar\&form=searchHomePage\&_offences_offenceCategory_offenceSubcategory=deception\%7Cforgery \&fromYear=1812\&fromMonth=01\&toYear $=1812$ \&toMonth $=11 \& \operatorname{start}=10]$.

61 Law Magazine, 35 (1846, p. 59).

62 May (2003, p. 34).

63 Proceedings of the Old Bailey, search for forgery cases in 1812, (accessed 5 July 2008) [http ://www. oldbaileyonline.org/search.jsp ?foo=bar\&form=searchHomePage\&_offences_offenceCategory_offe nceSubcategory=deception $\% 7$ Cforgery\&fromYear $=1812 \&$ fromMonth $=01 \&$ to Year $=1812 \&$ toMonth $=11 \&$ start $=0]$.

${ }^{64}$ Langbein (2003, p. 315).

65 May (2003, pp. 84-85).

66 FI, Colley Smith to Jackson 28 October, 1812. 
and four of them worked in the West End district he usually frequented, they were unlikely to be sympathetic ${ }^{67}$. By all accounts, William's defence witnesses would not have helped his case at all. The two who appeared turned out to be a courtesan and a brothel keeper, and another failed to materialise at all. Smith despaired that their evidence would "have made the prosecutor's case rather than the prisoner's and he could find no character witnesses to sway the jury either" 68 . For a youth of William's social standing the lack of such witnesses would have made a poor impression, and in forgery trials the gentility of the defendant and the efforts of his respectable friends to save his life tended to draw the greatest sympathy. Mr Jackson did agree to provide a new suit of mourning clothes for William to wear at his trial - not his son's preferred style - but given the importance of respectable appearance in forgery trials, probably a prudent one ${ }^{69}$. The judge in this case, Sir Allan Chambre, had a reputation for being scrupulously fair but severe in his sentencing ${ }^{70}$. Yet witnesses, judge and jury, played only minor roles in this trial. Peter Alley managed to show that the linen draper could not offer enough evidence to prove William's identity a common problem in forgery cases that required exacting standards of proof and a tactic used successfully earlier that year - before he needed to call any defence witnesses ${ }^{71}$.

Historians have used forgery trials, which involved the disputation of complex proofs in cases concerning wealthy defendants who could afford skilled counsel, in order to examine the growing influence of lawyers in the courtroom. The strict limitations on the role of counsel in court meant that raising technical objections could prove a useful tactic, particularly in forgery cases, and it was one Peter Alley frequently employed ${ }^{72}$. Adherence to strict legal procedure has been viewed as both upholding popular belief in the equality of justice for rich and poor, and as usually benefitting the defendant. But the increasing number of acquittals on legal technicalities from the late eighteenth century has also been linked to a growing aversion to capital punishment ${ }^{73}$. McGowen argues that judges did not interpret legal rules strictly simply on humanitarian grounds to prevent an excessive number of executions. In forgery cases they also had to navigate between the competing demands of being seen to punish what was regarded as a dangerous crime (committed by respectable citizens who engendered public sympathy) with a capital sentence that was rarely reprieved, in the face of challenging objections from counsel. He suggests that the "social class and the unfortunate predicament" of respectable defendants persuaded many judges to call on their colleagues for learned support when faced with lawyers legal objections. Judge Chambre appears to have conceded

\footnotetext{
67 London Metropolitan Archives, OB/SR/455, Old Bailey Sessions Rolls, 28 October 1812.

68 FI, Colley Smith to Jackson 28 October, 1812.

69 McGowen (1999, pp. 138-139); Andrew, McGowen (2001, pp. 219-220) on Mrs Rudd, whose "taste of decent elegance" in wearing mourning clothes made a very favourable impression at her trial in 1775 .

70 Oldham (2004).

71 For a case in which similar tactics were used see The Proceedings of the Old Bailey Online (hereafter $O B P$ ) www.oldbaileyonline.org [accessed 6 July 2008] trial of Joseph Thompson t18120408-1, April 1812; trial of William Jackson t18121028-4, October 1812; On problematic evidence and procedural objections in forgery cases see McGowen (1996, pp. 122-126, 2011, pp. 229-244).

72 McGowen (2011, pp. 246 \& 249).

73 Langbein (2003, pp. 166-167 \& 334-336); McGowen (2011, pp. 223-225 \& 253-257).
} 
Alley's point without recourse to the twelve judges, but the odds of success for such appeals after an unfavourable verdict in forgery cases were not good (around 40\%). This suggests that the judges did not necessarily give way to the lawyers or prioritise humanitarian concerns for genteel defendants ${ }^{74}$. Nevertheless, it remained common for counsel to use objections in forgery cases and in this case, the skills of William's defence counsel in raising them ensured that his life was saved, even if it was at the expense of truth.

Thus far hiring skilled defence counsel had secured the primary objective of saving William's life, but now Mr Jackson hoped that he would be convicted and imprisoned or transported on another charge. In the second trial, for theft from a lodging house, the judge was Sir John Sylvester, the recorder of London. He had a reputation for severity, wholehearted support of the 'bloody code' and a character that did not "inspire respect for the judicial office" 75 . But the trial had barely got under way when Alley trapped the prosecutor into admitting that he had let the whole of the house and not just apartments to William - in which case the owner's possession of the property temporarily ceased and the hirer had a right to do as he wished with the contents ${ }^{76}$. Probably to ensure an acquittal that would get rid of the attaint of felony while at the same time complying with Jackson's wishes, Alley also 'intimated' that William would plead guilty to the third charge of fraud if found innocent of this theft. Sylvester accepted the ensuing acquittal but lectured William "with great severity (...) on the enormity of his conduct" attend William's third appearance and there is no record of it in the Sessions Papers. The attorney Fletcher, however, reported that William pleaded not guilty and as both the prosecutor's "indictment and evidence were defective" he was again acquitted on technicalities. Alley and Adolphus were both present but it is not clear what role they played in this case. Afterwards, however, they both 'remonstrated' with William on the grossness of his conduct. Given that Alley had also requested that the prosecutor in the theft case be awarded costs, ${ }^{78}$ their behaviour at the last two trials suggests that both counsel were aware of their client's guilt and not altogether comfortable with their role in his complete discharge. Moreover, unlike those plebeian parents who increasingly saw the courts take action against their delinquent offspring, Jackson's desire to see that William was 'taken care of' by the Court, was thwarted despite and in many ways, because of - his wealth ${ }^{79}$.

William's acquittal on six counts of forgery and two charges of theft and fraud would therefore support both a case for the advantages of wealth in hiring solicitors and counsel for the defence, and that truth could be one of the casualties of adversarial trial. Yet it is less clear whether this was a defect limited to the English system in the early nineteenth century. ${ }^{80}$. For Langbein the growing aversion to

\footnotetext{
$74 \quad$ Ibid. (p. 254).

75 May (2004).

76 OBP trial of William Jackson t18121028-12, October 1812 [accessed 6 July 2008]. For an explanation of the legal position see Bevill (1799, pp. 244-246).

77 FI, Colley Smith to Jackson 29 October 1812.

78 London Metropolitan Archives, OBSP/RSB/13, shows costs were awarded to Colville and one witness.

79 King (1998).

80 Langbein (2003, p. 2); Cairns (1998, p. 124).
} 
capital punishment was a significant factor affecting British tolerance for the "truth defeating consequences" of adversarial trial, since the large number of capital crimes meant that too much truth would result in too much death ${ }^{81}$. Cottu commented that the English people seemed "indifferent whether, among the really guilty, such be convicted or acquitted" and contrasted this with the "ardent desire in France to find out the truth". Yet there was much he admired about the English system that he sought to apply to the French and he praised the restrictions placed on both prosecuting and defence counsel ${ }^{82}$.

We do not hear the prosecutor's counsel paint the prisoner as a monster of whom the earth ought to be that instant rid, and compare him to all villains who have astonished the world by their enormities. Nor do we see the prisoner's counsel offering to the jury a thousand idle surmises on the manner in which it is possible the crime may have been committed nor see him belying his own conscience, inducing the jury to betray theirs, and threatening them with divine judgement, should they dare to do their duty. No one has the right to pervert the light of the evidence by subjecting it to the prism of his own opinion or imagination: the jury receive it in all its purity ${ }^{83}$.

Much of the excessive zeal employed by the defence in France was intended to counteract the opening indictment, drawn up by the public prosecutor, which has been described as more akin to a speech for the prosecution. Hence French barristers resorted to "throwing doubt on the most irrefragable proofs; fabricating suppositions devoid of all probability" and, "thus derived a vain and empty joy in having snatched a scoundrel from due punishment" ${ }^{\prime 4}$. Modern scholars have also argued that other truth-defeating activities, such as jury nullification, were practised in French as well as English courts in this period. Moreover, while Langbein and Cairns have highlighted how the use of exclusionary rules of evidence in English courts resulted in guilty defendants being acquitted, Donovan has argued that the lack of rules of evidence to guide the jury on how to judge the relative weight of contradictory evidence resulted in particularly high acquittal rates in France. ${ }^{85}$

Skilled counsel played an equally important role during William's later trial for fraud at Gloucester Assizes in March 1813, and again money proved a significant factor. In this case however, the balance of funding and legal advice was very much in favour of the prosecution, although William's gentility did initially work in his favour. William and Joseph Bradley, the son of a respectable merchant that he had met while they were both imprisoned for debt in the Fleet, were arrested in Cheltenham and charged with obtaining goods by deception from goldsmith Walter Meyer. They had paid for two gold watches and a diamond ring with a draft drawn upon a local surgeon and apparently guaranteed by Sir George Shee. During pretrial proceedings the high status connections and obvious gentility of the young men engaged public and even some judicial sympathy. Mr Jackson received letters

\footnotetext{
$81 \quad$ Langbein (2003, pp. 334-337).

82 Cottu (1822, pp. 92, \& 280-312 devotes a whole chapter to explaining how examples of English practice could be used to improve the French system. But Cairns (1998, p.13 nt. 26) describes Cottu's account as "rather laudatory".

83 Cottu (1822, pp. 89-90).

$84 \quad$ Ibid., pp. 270-271.

85 Langbein (2003, p. 336); Cairns (1998, pp. 124-125); Donovan (2010, pp. 12-13 \& 31-32).
} 
from an Irish colonel, offering his support and that of at least five other wealthy influential friends in Cheltenham ${ }^{86}$. Mr Jackson declared that he would not "advance a shilling to aid his escape from the hands of justice" and refused all offers of help from high-ranking friends ${ }^{87}$. Jackson even rejected the sympathy of the deceived surgeon, who was clearly a family friend. By way of reply he painted William's character in such black terms that it convinced the surgeon to take the stand as a key prosecution witness ${ }^{88}$. The local press however, were favourably impressed with both defendants' respectability and noted approvingly that the magistrates at the committal hearing "behaved in a most gentlemanly manner, extending every lenity compatible with their office" 89 . Nevertheless, on hearing that the pair may have committed other crimes, the Cheltenham magistrates contacted Bow Street police office in London and on learning that this was true, committed them for trial at Gloucester Assizes. They were taken to the new gaol at Gloucester where the compulsory uniform, and rigorous system of isolation, hygiene and obedience designed to enforce humility and erase difference had little effect on William. He still managed to rent gentlemen's apartments in the gatehouse until his trial and placed an advertisement in a Cheltenham newspaper announcing he would shortly publish a pamphlet entitled Cheltenham Unmasked denouncing his enemies. He spent a great deal of time preparing his defence, which he claimed he was sending to counsel for advice and even that he was corresponding with Adolphus, his Old Bailey barrister, but there is no evidence to support either assertion. He also sent copies of his case to Lord Folkstone and Sir Francis Burdett, whom he hoped would support him ${ }^{90}$. Since none of his family connections were prepared to help him, there was no possibility of engaging in any pre-trial negotiation with the prosecutor and the outcome of his trial would depend primarily on the skills of competing counsel and the strength of the evidence presented.

Walter Meyer, the deceived goldsmith, was a member of the Cheltenham Crime Association who paid for the services of two solicitors to prepare the case and three counsel to prosecute it. The Association would also have arranged for witnesses to be subpoenaed and, paid for them and the prosecutor to be taken to Gloucester and housed in suitable accommodation ${ }^{91}$. It is perhaps ironic, but also indicative of Jackson's attitude towards his son's prosecution, that he was himself a member of the Langley Association for the Detection of Thieves and Felons ${ }^{92}$. William later claimed that "he was found guilty because he had no counsel", but a newspaper report shows that he and Joseph Bradley shared a single barrister, $\mathrm{Mr}$ Ludlow ${ }^{93}$. William's comment almost certainly reflected his belief that he had no skilled legal advice of the kind he had benefitted from at the Old Bailey. Without family support he had no money to pay for an attorney or counsel so unless Bradley's

\footnotetext{
$86 \quad$ FI, Col W Caulfield Lennon to Jackson, 1 March 1813.

87 FI, Jackson to Colley Smith, 24 March 1813.

88 FI, Dr Thomas Newell to Jackson, 1 March 1813; Jackson to Newell, 2 March 1813; TNA, ASSI5/133/4 Gloucester Assizes, 1813; Jackson to Huddlestone, 2 August 1813.

89 FI, Extract from Cheltenham Newspaper, 4 March 1813, cited by Jackson.

90 TNA, C106/69, William to Jane Jackson, 5 March 1813.

91 Philips (1989, p. 138).

92 TNA C 106/69 poster advertising a meeting of the Association listing Jackson as a subscriber.

93 FI, Jackson's note before copy of Cheltenham newspaper report of trial.
} 
family had supplied funds, their barrister was probably only a trainee appointed by the court at short notice, without a thoroughly prepared brief. Even if Ludlow had been more experienced, most counsel acting at County Assizes usually arrived late in the evening before the sessions began and had no contact with the attorneys until the following morning at nine. This left only a few hours before the sessions commenced to study their brief ${ }^{4}$. There is no record of defence witnesses but both defendants took copious notes throughout the proceedings - perhaps to help instruct their barrister. The earnest Mr Ludlow apparently delivered "an able speech" to try and convince the jury that, despite the obvious imprudence of their actions, the prisoners had never intended to defraud the goldsmith. Unlike in the French cours d'assises, where information about previous offences and hearsay evidence were allowed, Judge Bayley sought to counteract the effects of the publicity surrounding the case by reminding the jury not to take into account anything they had heard prior to this trial. In summing up the evidence Bayley charged them to decide whether it was the prisoners' 'pretence' of knowing the surgeon and asserting that he would honour their draft that had persuaded Meyer to give them the jewellery. The jury, showing no signs of sympathy for youth or gentility, barely took time to confer before pronouncing the pair guilty. On being asked if they had anything to say before sentence was pronounced, both assured the court that they had not intended to cheat the prosecutor ${ }^{95}$. Their speeches made no impression on the judge.

Bayley was both popular with his fellow judges and counsel in King's Bench and greatly respected for his mastery of the common law. He was also considered to have perfected the solemn art of passing judgement in court ${ }^{96}$. William expected to be sentenced to a period of hard labour for being found guilty of obtaining goods by false pretences, normally classified as a misdemeanour. Judge Bayley sentenced them to seven years transportation. In doing so Bayley explained that they had offered a draft on a bank in which they knew they had no money to cover a purchase, and had clearly intended to cheat the vendor. This suggests that, in sentencing, Bayley believed both youths were guilty of larceny by trick (a felony) since their deception was part of a clear intention to steal goods against the owner's will ${ }^{97}$. Research has shown that in post-verdict proceedings wealth could also count against a criminal, and in this case it is possible that Bayley chose the strictest interpretation of William and Bradley's crime because of their privileged backgrounds ${ }^{98}$. Certainly when sentencing them, Bayley drew attention to the way that the defendants' wealth and respectability made their crime less excusable, by explaining that

it was most painful to him to see young men of apparent respectability, and whose education (...) ought to have taught them better conduct, in the situation they were, associated with felons of the worst description; and remarked, with much feeling, the distress and pain they had brought upon their friends by such abandoned conduct ${ }^{99}$.

\footnotetext{
94 Langbein (2003, pp. 256-257, nt. 16); Cairns (1998, pp. 37-38, nt. 67).

95 This account of the trial is taken from the Cheltenham \& Gloucester Advertiser, 8 April 1813.

96 Lobban (2004).

97 My thanks to Professor Michael Lobban, School of Law, Queen Mary College, University of London, for clarifying and explaining this legal distinction.

98 Langbein (2003, p. 113); King (2000, p. 307).

99 Cheltenham \& Gloucester Advertiser, 8 April 1813.
} 


\section{III}

The last stage of the criminal justice system at which historians have disputed the extent to which respectability and social status could play a pivotal role was the pardoning process. Recent research has indicated that judicial considerations - youth, respectability, the likelihood of reformation and a first offence being the most common - outweighed elite influence ${ }^{100}$ Gattrell records a rapid rise in petitions during the early nineteenth century when criticism of hanging and the exercise of judicial discretion made the granting of mercy to temper the system appear even more important. Yet both judges and the Home Office sought to contain elite expectations of influence and by the 1820s most such petitions were refused unless backed by new evidence ${ }^{101}$. Judge Bayley's sentencing of William at Gloucester in March 1813, during which he emphasised that the conviction was based on "evidence so clear as to leave no doubt", suggests that he would have been unlikely to recommend an administrative pardon after the trial, even if William's family had asked for one ${ }^{102}$. Judges' willingness to pardon has also been shown to relate to their personal assessment of current levels of unrest and high crime rates. Bayley had expressed dismay to the Grand Jury at "the length and enormity of crimes with which the calendar abounded" at Gloucester. Barely two months earlier Luddites convicted at York Assizes had been speedily hung to prevent applications for mercy ${ }^{103}$. William was moved from Gloucester gaol to await transportation on board the hulk Retribution at Woolwich where, for the first time, his status made no difference to his treatment.

Despite lack of family support, William began to seek a pardon from the Prince Regent, convinced that his high ranking connections would be able to swing the levers of power in his favour. Recently Hay has reiterated the importance of elite 'connections', arguing that their influence was expressed more or less overtly depending on current attitudes to capital punishment and games of patronage: he suggests the regency was one of those periods when more overt expressions of influence were possible. One problem with gauging 'influence', as Hay points out, is that it is not always visible in the official pardon files most commonly studied by historians $\mathrm{s}^{104}$. The subtle ways that personal relations of power and unspoken assumptions about social status operated are often not recorded but, as in this case, traces can be found in family correspondence. William described to his father how

My friend Sir John Peshall Bart., has exerted himself greatly on my behalf (...) He not only signed my petition but got Lord Warwick likewise to sign it, with a strong recommendation; and the Honorable Mr Sheridan handed it to the secretary of state. Should it not succeed, Colonel Macmahon, through the interest of Colonel O'Kelly of Half Moon Street, who has strongly advocated my cause, has kindly promised to hand another petition for me personally to the Prince.

\footnotetext{
100 King (2000, pp. 295-333).

101 Gattrell (1994, pp. 204-207 \& 525-526).

102 Cheltenham \& Gloucester Advertiser, 8 April 1813.

103 Ibid.; Hay (2011, pp. 145-146), also notes Bayley had not been chosen to sit at York, because he had been considered too lenient during Luddite trials at Nottingham the previous year.

104 Hay (2006, pp. 6-18).
} 
Indeed, should a full pardon not be possible he assured his father that "one word from Sir George Shee to Lord Sidmouth would obtain for me a conditional pardon to leave the country for the space of my sentence" 105 . For wealthy convicts self-exile was one way to escape the full rigour of punishment and conceal the taint of criminal conviction. As Gatrell has shown, pleas for special treatment from high born and better educated prisoners during transportation were often viewed sympathetically. Although the sentence would not necessarily be mitigated its conditions could be ameliorated: by separation from lower born convicts or an extra luggage allowance during the voyage ${ }^{106}$.

Although most judges resisted the influence of the gentry when making pardoning decisions, as King notes, the intervention of an MP could still ensure that 'the claims of class' took precedence. The additional possibility of making a direct petition to the monarch via the secretary of state also meant that for respectable convicts, the support of a sympathetic peer could be "the greatest good fortune" 107 . In the event, however, the political influence of William's connections did not prove weighty enough to sway the scales of justice, not least because of a clash of private and political interests at the highest levels. A number of the eminent gentlemen William was relying upon suddenly found themselves out of favour with the Prince Regent. The brilliant playwright and politician Richard Brinsley Sheridan, was himself being pursued for debt and had quarrelled publicly with the Prince over money he had borrowed to purchase a parliamentary seat. Colonel Sir John MacMahon, was the Prince's private secretary but he had lost his Parliamentary seat and the Whigs were no longer in favour with the Regent. The failure of William's petition however, was primarily due to Sir George Shee's refusal to exert his influence. Sheridan reported that his letter had been warmly received by Sidmouth, the Home Secretary, who promised to discuss the matter with his 'very particular friend, Sir George Shee' ${ }^{108}$. Almost certainly because the Jacksons would not agree to sanction Shee's support of William's cause, Sidmouth ultimately turned down his request for self-exile. Lord Warwick then sought the help of the newly appointed foreign secretary Lord Castlereagh, who had served with Shee in Ireland. Castlereagh agreed to recommend William to Sidmouth, but without success. Sheridan and Peshall tried again to gain some remission for William, but this time only to ensure that he could leave the hulks on board the first ship bound for Botany Bay. Thus, while William's elite connections promised much, their influence was undermined by divisions at court and fatally damaged by family intervention, so he remained on board Retribution for another six months.

The failure to obtain a pardon, however, did not mark the end of all opportunities for wealthy, well-connected convicts awaiting transportation to ameliorate their sentences. William found support from friends who opposed the system of transportation and wrote to Jane Jackson to persuade her to show some sympathy for her son's situation ${ }^{109}$. These letters and fears of never seeing her son again

\footnotetext{
105 FI, William to Jackson, 17 June 1813. No official record of William's petition survives.

106 Gattrell (1994, p. 528).

107 King (2000, p. 332); Hay (1975, pp. 44, 46).

108 TNA, C106/69, William to Jane Jackson, 17 February 1814

109 TNA, C106/69, letters from Lt. Fitzgerald to Jane Jackson, 4 August 1813, 8 \& 10 January 1814.
} 
eventually convinced Jane Jackson to help him. William asked her to persuade her old friend Lady Kennedy, whose husband, Sir Robert Kennedy, was Commissary General in the Army, to secure him a pardon on reaching New South Wales. By then he would have "served nearly two years, and God knows that is punishment too great for the nature of my offence" 110 . William also had the support of another army officer with whom he had once served and who offered to write to the Deputy Governor of New South Wales, Col. O'Connell of the $73^{\text {rd }}$ Regiment. William was, therefore, cautiously optimistic about his chances of achieving freedom on arrival in Sydney, but he was unaware that O'Connell would have left the colony before he arrived.

Even if a pardon was not forthcoming on arrival, many of the transportees also seem to have been well-informed about how letters and money could be sent ahead, or smuggled ashore when the transport ship docked in Sydney, to ensure better treatment. William learnt from convicts and crew on board the Surry, that he needed to make contact with Rev. Samuel Marsden, a "Magistrate and man of Consequence in New South Wales", who could be trusted with any supportive letters sent from England ${ }^{111}$. In this way the well-connected, particularly the well-educated, could obtain positions as tutors and clerks instead of being sent to work on farms or the town gangs. Distinctions of wealth and rank affected the way that convicts were treated in the penal colony just as they had in Newgate and other unreformed English prisons. Indeed, a convict who arrived in possession of money could make a deal with a settler who would agree to be his nominal master, but would expect no work from him in return for suitable remuneration ${ }^{112}$. Hence William's prospects appeared to be improving when he set sail in the Surry in February 1814 and found that his status meant that the Captain and surgeon treated him better than the ordinary prisoners on the transport ship. But the ship was struck with typhus and became one of the most infamous to make the crossing, losing 51 men including the captain, surgeon and many of the crew on the way. No letters had reached Sydney by the time the Surry limped into port, so instead of the special treatment he expected on arrival, William was forced to work as a convict labourer until receiving a sudden remittance of his sentence in September 1815. At that time he was serving a secondary sentence in the penal colony of Newcastle, so the most likely explanation for his sudden release is that letters from friends or family had finally managed to secure him a ticket of leave. It was a limited form of freedom but also a first step towards a pardon ${ }^{113}$. The fact that his father had died in 1814 and William had begun to receive a large annuity under the terms of his will almost certainly also helped his case. Governor Macquarie had laid down a minimum of three years before a convict could apply for a ticket of leave, but he often broke his own rule and was known to be flexible in his approach to pardoning convicts. While he was particularly keen to reward

\footnotetext{
$\overline{110}$ Ibid., William to Jane Jacson, 17 February 1814.

111 Ibid., William, from Rio de Janeiro, to Jane Jackson, 12 April 1814.

112 See Bigge (1822), pp. 16-18, on convicts' efforts to influence their future service; Hughes (2003, pp. 349-350) on 'Specials', educated convicts, usually from elite families, who secured posts as teachers and clerks.

113 A ticket of leave granted a convict the right to seek employment within a specified area, but he had to report regularly to the authorities and attend religious service. A pardon could be either conditional, which conferred freedom within the colony; or, absolute, which allowed the ex-convict to leave the continent and return to Britain.
} 
good behaviour Macquarie also believed that "the claims of gentlemen could not be overlooked". A Parliamentary Select Committee had expressed concerns about the system in 1812, but it was not until the recommendations of Commissioner John Bigge's Reports began to be implemented during 1820s and 1830s that the rules were tightened $^{114}$. Macquarie granted William a conditional pardon (which also conferred a sizeable grant of land) in January 1818 - three years before his sentence was due to expire ${ }^{115}$. Thus wealth and social status appear to have gained William more of an advantage under the flexible system of pardoning adopted in early nineteenthcentury Australia, where claims of class closely mirrored those made, but perhaps less frequently heeded, in the mother country.

A case study, while much richer in depth, can only provide very limited evidence of broader trends. Nevertheless this case suggests that high ranking families expected their wealth and status to make a difference, and at many points it clearly had the potential to do so if they chose to exercise that advantage. Throughout his journey through the criminal justice system William believed that claims of class should guarantee him better treatment than that of common criminals and he expected the influence of high ranking family and friends to work in his favour. Since he never felt any guilt for his actions, he also believed that his acquittal or conviction in court depended primarily on the efforts of skilled solicitors and barristers rather than the strength of the evidence against him. It seems clear that this was the case at the Old Bailey and that both his solicitor and counsel knew that their efforts benefited their client but not the truth; whereas at Gloucester the strength of the prosecution team weighed heavily against William. The ability to pay for, and particularly the tactics pursued by, skilled barristers and attorneys had the most significant impact on trial outcomes. The 'wealth effect' resulted in unjust acquittals at the Old Bailey and the use of legal objections in court was particularly effective in this case. Yet adversarial practice in French courts was often even more combative and acquittal levels there were also high in this period. Mr Jackson exhibited an unwavering belief in the equality of English justice from which no-one, no matter what their rank, was exempt. Since he saw it as a system operating for the public good he believed that the law should 'remove' anyone who threatened public rights. But his use of the system was also instrumental. He exhibited a tension between his public duty to protect others and his private desire to control his son and remove the threat to his wealth, his family and his own status in the community. He refused to shield William from justice, but clearly used his wealth to manipulate the system: to buy legal counsel to achieve the desired level of 'removal' (imprisonment or transportation, but not death) or, by withholding funds to ensure his son's conviction. Jackson similarly prevented family and friends from exercising any social influence, but it was during the pardoning process that this seems to have had the most impact. Hence this case study suggests that the impact of wealth on the early-nineteenth-century criminal justice system should not be regarded as solely a matter of purchasing legal assistance, or exercising elite influence. It was also tied up with more complex individual family politics,

\footnotetext{
114 Hirst (1983, pp. 53-54 \& 86-88).

115 State Records of New South Wales, Petition of William Collins Burke Jackson: 4/1851, Colonial Secretary's Letters, p.186, microfiche 3178; Conditional Pardon Burke Jackson (31 January 1818), 4/4430, p. 120 , reel 774 .
} 
which determined when and how such advantages might be applied to the levers of justice, or abandoned altogether.

\author{
Dr Nicola Phillips \\ Dept of History \\ Faculty of Arts and Social Science \\ Kingston University \\ Penrhyn Road \\ Kingston-upon-Thames \\ Surrey KT1 2EE \\ N.Phillips@kingston.ac.uk
}

\title{
BIBLIOGRAPHY
}

Andrew, D.T., McGowen, R., The Perreaus and Mrs Rudd: Forgery and Betrayal in Eighteenth Century London, London, University of California Press, 2001.

Barker, G.R.F., 'Scarlett, James first Baron Abinger (1769-1844)', rev. Elisabeth A. Cawthon, Oxford Dictionary of National Biography, OUP, 2004 [http ://www.oxforddnb.com/view/ article/24783], accessed 2 Oct. 2012.

Beattie, J.M., Crime and the Courts in England, 1660-1800, Oxford, Oxford University Press, 1986.

Bevill, R., A Treatise on the Law of Homicide and of Larceny at Common Law, London, 1799.

Bigge, J.T., Report of the Commissioner of Enquiry into the State of the Colony of New South Wales, (1822) from ProQuest, House of Commons Parliamentary Papers Online [accessed 30 August 2012].

Blackstone W., Commentaries on the law of England, Oxford, 1765-69 from The Avalon Project at [http://www.yale.edu/lawweb/avalon/blackstone/bk4ch2.htm], accessed 27 June 2008.

Brewer, J., J.Styles, J., An Ungovernable People: The English and their law in the seventeenth and eighteenth centuries, New Brunswick, Rutgers University Press, 1980.

Cairns, D.J., Advocacy and the Making of the Adversarial Criminal Trial, 1800-1865, Oxford, Clarendon, 1998.

Corfield, P.J., Power and the Professions in Britain, 1700-1850, London, Routledge, 1995.

Cottu, C., On the Administration of Criminal Justice in England; and the Spirit of the English Government (Translated from the French), London, 1822.

Donovan, J.M., Juries and the Transformation of Criminal Justice in France in the Nineteenth \& Twentieth Centuries, Chapel Hill, University of North Carolina Press, 2010.

Dwyer, D., Review of Origins of Adversary Criminal Trial, The Modern Law Review, 2003, 66, pp. 940-944, from HeinOnline [http ://heinonline.org], accessed 9 July, 2012.

Emsley, C., Law Reform and Penal Reform in England in the Age of the French Revolution, in Rousseaux, X., Dupont-Bouchat, M.S., Vael, C. (dir.), Révolutions et justice pénale en Europe: Modèles français et traditions nationales, 1780-1830 / Revolution and Criminal Justice: French Models and National Traditions, Paris and Montreal, L'Harmattan, 1999, p. 319 nt. 1.

Emsley, C., Crime and Society in England, 1750-1900, Harlow, $4^{\text {th }}$ edn., 2005.

Finn, M., The Character of Credit: Personal Debt in English Culture, 1740-1914, Cambridge, CUP, 2003. 
Gattrell, V.A.C., The Hanging Tree: Execution and the English People, 1770-1868, Oxford, OUP, 1994.

Griffiths, B., On Not Becoming Delinquent: Raising Adolescent Boys in the Dutch Republic, 1600-1750, in Cox, P., Shore, H. (Eds) Becoming Delinquent: British and European Youth, 1650-1950, Aldershot, Ashgate, 2002, pp. 41-58.

Handler, P., Review of Origins of Adversary Criminal Trial, The Cambridge Law Journal, 2004, 63, pp. 517-518.

Hansard, Parliamentary Debates, vols.18, 24, London, 1814.

Hay, D., Property, Authority and the Criminal Law, in Hay, D., Linebaugh, P., Rule, J.G., Thompson, E.P., Winslow, C. (Eds), Albion's Fatal Tree: Crime and Society in Eighteenth Century England, London, Allen Lane, 1975, pp. 17-63.

Hay, D., Prosecution and Power: Malicious Prosecution in the English Courts, 1750-1850, in Hay, D., Snyder, F., Policing and Prosecution in Britain, 1750-1850, Oxford, Clarendon, 1989, p. 39.

Hay, D., Writing about the Death Penalty, Legal History, 2006, 10, 1-2, pp. 13-52, SSRN [http://ssrn.com/abstract=1884278], accessed 26 October 2012.

Hay, D., Hanging and the English Judges : The Judicial Politics of Retention and Abolition, in Garland, D., McGowen, R., Meranze, M. (Eds), America's Death Penalty: Between Past and Present, London, New York University Press, 2011, pp. 145-146.

Hirst, J.B., Convict Society and its Enemies: A History of Early New South Wales, Sydney, Allen \& Unwin, 1983.

Hooper, A., Lord Justice, Review of 'Origins of Adversary Criminal Trial', The International Journal of Evidence \& Proof, 2004, 8, p. 206-13, HeinOnline [http://heinonline.org], accessed 9 July, 2012.

Hunt, M., The Middling Sort: Commerce, Gender and the Family in England, 1660-1780, London, University of California Press, 1996.

Ignatieff, M., A Just Measure of Pain: The Penitentiary in the Industrial Revolution, 17501850, London, Penguin, 1989.

Innes, J., Styles, J., The Crime Wave: Recent Writing on Crime and Criminal Justice in Eighteenth-Century England, Journal of British Studies, 1986, 25, 4, pp. 380-435.

King, P., Decision-Makers and Decision Making in the Eighteenth-Century Criminal Law, The Historical Journal, 1984, 27, 1, pp. 25-58.

King, P., The Rise of Juvenile Delinquency in England 1780-1840: Changing Patterns of Perception and Prosecution, Past and Present, 1998, 160, pp. 116-166.

King, P., Crime, Justice and Discretion in England, 1740-1820, Oxford, OUP, 2000.

Langbein, J., Albion's Fatal Flaws, Past and Present, 1983, 98, pp. 96-120.

Langbein, J., The Origins of Adversary Criminal Trial, Oxford, OUP, 2003.

Lis, C., Soly, H., Disordered Lives: Eighteenth-Century Families and their Unruly Relatives, Cambridge, Polity Press, 1996.

Lobban, M., Bayley, Sir John, first baronet (1753-1841), Oxford Dictionary of National Biography, Oxford, OUP, 2004 [http ://www.oxforddnb.com/view/article/1752], accessed 28 May 2009.

May, A.N., The Bar \& the Old Bailey, 1750-1850, Chapel Hill and London, University of North Carolina Press, 2003.

May, A.N., Silvester, Sir John, first baronet (1745-1822), Oxford Dictionary of National Biography, Oxford, OUP, 2004 [http ://www.oxforddnb.com/view/article/67764].

McGowen, R., Forgery Discovered, or the perils of circulation in eighteenth-century England, Angelaki, 1996, 1, pp. 113-130.

McGowen, R., From Pillory to Gallows : The punishment of forgery in the age of the financial revolution, Past and Present, 1999, 165, pp. 107-140. 
McGowen, R., Forgery and the Twelve Judges in Eighteenth-Century England, Law and History Review, 2011, 29, pp. 221-257, HeinOnline [http://heinonline.org], accessed 15 October 2012.

Melikan, R.A., Romilly, Sir Samuel (1757-1818), Oxford Dictionary of National Biography, Oxford, OUP, 2004 [http://www.oxforddnb.com/view/article/24050], accessed 26 September 2012.

More, S., The Cheapside Apprentice : or, The History of Mr Francis H, London, 1796.

Mr. Adolphus and his contemporaries at the Old Bailey, Law Magazine, 1846, 35, pp. 54-67.

Neild, J., State of the Prisons in England, Scotland and Wales, London, 1812.

Oldham, J., Chambré, Sir Alan (1739-1823), Oxford Dictionary of National Biography, Oxford, OUP, 2004 [www.oxforddnb.com/view/article/5086], accessed 22 April 2008.

Philips, D., Good Men to Associate and Bad Men to Conspire: Associations for the Prosecution of Felons in England, 1760-1860, in Hay, D., Snyder, F. (Eds), Policing and Prosecution in Britain, 1750-1850, Oxford, Clarendon, 1989, p. 138.

Sharpe, J.A., Crime in Early Modern England, 1550-1750, Harlow, Longman, $2^{\text {nd }}$ edn, 1999.

Shore, H., Artful Dodgers : Youth and Crime in Early Nineteenth Century London, Woodbridge, Boydell Press, 1999a.

Shore, H., Home, play and street life : causes of and explanations for juvenile crime in the early nineteenth century, in Fletcher, A., Hussey, S. (Eds), Childhood in Question: Children, Parents and the State, Manchester, Manchester University Press, 1999b, pp. 108-109.

Spierenburg, P., The Prison Experience: Disciplinary Institutions and Their Inmates in Early Modern Europe, Amsterdam, Amsterdam University Press, 2007. 